\title{
Business Administration Students in Five Canadian Universities: A Study of Values
}

\author{
SLAVEK J. HURKA, Ph.D.*
}

\begin{abstract}
Using the Allport-Vernon-Lindzey (AVL) for measuring dominant values, 513 business administration students from five schools in the Prairie Region were tested. The AVL scale measures relative importance of student values in six basic areas: theoretical, economic, aesthetic, social, political and religious. The sample included 349 men and 164 women enrolled in different class levels (years 1 to 4) in five schools of business.

Significant differences were found between business student values and the norms for the general college population, and between the values of male and female business administration students. Differences were progressively less significant when business students were compared by class levels and by schools.
\end{abstract}

\section{RÉSUMÉ}

En utilisant l'échelle Allport-Vernon-Lindzey (AVL) pour mesurer les valeurs dominantes, on a échantilloné 513 étudiants des cours d'administration commerciale à cinq établissements de la région des Prairies. L'échelle AVL mesure l'importance relative des valeurs des étudiants dans six champs fondamentaux: les domaines théorique, économique, esthétique, social, politique et religieux. L'échantillon comprenait 349 hommes et 164 femmes inscrits à divers niveaux (première année jusqu'à la quatrième année) de cinq écoles d'administration. On a constaté des différences significatives entre les valeurs des étudiants en administration et les normes pour la population générale des établissements post-secondaires, et aussi entre les valeurs des étudiants mâles et celles des étudiants femelles en administration commerciale. Les différences se faisaient progressivement moins significatives quand on comparait entre eux les étudiants en administration de différentes années ou fréquentant différentes établissements.

*Associate Professor of Organizational Behavior, College of Commerce, University of Saskatchewan. 
A review of relevant literature indicates a surge of interest in the possible effects of college experience on personality characteristics of students. Two major studies dealing with this issue have resulted in quite different conclusions. After an extensive survey of the literature on the change in college students, Jacob (1957) reached the conclusion that college experience has little impact on values and personality attributes. In a more recent study by Feldman and Newcomb (1969), however, this view is not supported. Their study, which also reviewed the literature on the impact of collegiate experience upon students, found that changes in student values did indeed take place during their college experience. Differences in student values were related to types of institutions, curricular programs and stages of the programs.

During the past decade many studies have been conducted in an attempt to find out more about students enrolled in higher education. In general, their aim was not only to further the existing knowledge in the field, but also, particularly in professional colleges, to use the findings as a guide for developing new programs and revising existing ones. (Garvin, 1976). Some of the research dealing with values of college students has indicated changes in student values at different class levels. The most consistent changes revealed from the samples studies occurred in religious and aesthetic values, as measured by the Allport-Vernon-Lindzey Study of Values scale (1970). Most of the studies indicated that aesthetic values are of higher importance to students who are completing their undergraduate education than to first year students, whereas religious values tend to be less important (Feldman and Newcomb, 1969, p. 8). The higher proportion of the studies recorded in the literature dealt with the "general" student population in the United States. Do these values also hold true for the business students in Canadian universities?

The purpose of this study was to investigate the values of students enrolled in five schools of business (commerce) in the Prairie Region, to compare the differences between class (year) levels and business schools, and to compare the business student values with the norms for the general college population. By ascertaining these value differences, inferences can be made as to what values the student brings to the business program, and which values appear to be more highly reinforced by the program. This may have implications for both curriculum development and the admission process.

The interest in this study is motivated by trends of the recent past. The data dealing with enrollment in higher education in Canada suggests a trend toward professional education. During the five-year period ending in the $1975-76$ academic year, the undergraduate student population in Canada increased overall by 15.1 percent. During the same five-year period, the number of students enrolled in schools of business rose by 47.4 percent (Statistics Canada, 1977). If this trend continues it may be that business schools, at both graduate and undergraduate levels, will require more than academic transcripts and references to evaluate from among the expanding number of applicants. A refined selection process usually leads to a consideration of values and attitudes.

This study, therefore, addresses itself to the current values found among business administration students, as reflected in the following four questions:

1. Are there differences between the value of students in business programs and the value norms for the general college population?

2. Are there differences between the values of male and female business administration students? 
85 Business Administration Students in Five Canadian Universities: A Study of Values

3. Are there differences in business student values at specific class (year) levels?

4. Are there differences in business student values in the different schools participating in this study?

\section{Methodology}

\section{Instrument}

The Allport-Vernon-Lindzey Study of Values (AVL) is probably the most widely used instrument for the study of dominant interest modes in personality. It contains 45 forced-choice items and is based on Spranger's (1928) work which holds that the personalities of man are best known through a study of their values or relative attitudes. The scale yields six scores which indicate the relative prominence of basic interest or "values" for an individual. The values can be summarized in the following manner (Allport, et al., 1970, p. 4, 5):

Theoretical - Main interest in the discovery of truth; attitudes are cognitive, empirical, critical, and rational; aim is to acquire a systematized knowledge. Economic - Interest in what is useful and practical; interest in consumption of goods and the accumulation of wealth; thinks education should be practical - unapplied knowledge is a waste.

Aesthetic - Values beauty, form and harmony; interest in people but not necessarily in their welfare; tends toward individualism and self-sufficiency. Social - Interest in people; has an altruistic, philanthropic love of people; regards love, as itself, the only suitable form of human relationship.

Political - Primary interest in power, competition, and struggle; often found in leadership positions.

Religious - Values unity; seeks to relate oneself to the universe as a whole; directs self to the creation of the highest and absolutely satisfying value experience.

The six sub-scales are not independent of each other since high score on one value (indicating strong interest) can be attained only by reducing the score on one or more of the other values. Since the AVL Study of Values is an instrument measuring relative value, the findings need to be interpreted with caution. The scale is designed mainly for use with college students or with others who have had some college education. It has been standardized on a college population of 8,369 subjects (Allport, et al, 1970, p.12) and norms are available for different college groups. Split half reliability for the six sub-scales ranged from .84 to .95 with a mean reliability coefficient of .90 (allport, et al., 1960, p.9).

\section{Data Collection and Sample}

The testing program was carried out during 1978, using selected classes to represent each year (level) of business administration students in five universities. Depending on the size of each class, between 20 and 30 students were randomly selected and invited to participate in the investigation. Each student was asked to complete a two-part questionnaire. The first part included background variables of the respondents; the second part was the AVL Study of Values scale. The investigator was present to answer questions involving details of procedure.

The final sample of 513 students included 145 first year, 120 second year, 121 third 
year and 127 fourth year students. The distribution by sex was 349 men and 164 women. Considering the large percentage of female students, and the fact that significant sex difference in values have been repeatedly reported in the literature, a male vs female breakdown was included in the data analysis.

\section{Data Analysis}

Means and standard deviations on each of the AVL scales of business students were compared to the norm means and standard deviations of general college students reported in the revised manual for the third edition of the Study of Values (Allport, et al., 1960). The AVL norms are considered to be a valid basis for comparison. Although developed in 1960 , they have been used in many recent studies, providing for an accumulation of data which allows a "common" comparison among different curricular groups. The studies subsequent to Allport et. al., support the conclusion that evaluative attitudes as measured by AVL scales are generalized traits of personality and that they are pervasive and enduring. There being no available data which dealt with the Canadian general college population, it was necessary to rely on American data under the assumption that student value norms between such close and similar cultures would not differ significantly.

$t$ test was used to test the significance of differences found. One-way analysis of variance was utilized to test the differences between the mean scores of business students enrolled at different class (year) levels. Analytic procedures in the Statistical Package for Social Sciences (Nie et al., 1970) and facilities of the University of Saskatchewan computer centre were used to process the data.

\section{RESULTS}

\section{Business versus General College Student Values}

The findings relative to the first question comparing values of business administration students with value norms for the general college population are shown in Tables 1 - 3 . These tables show the means, standard deviations and the tests of the significance of differences for the two groups of students.

The $t$ ratios and probability values in Table 1 indicate that there were statistically significant differences between the value of business students and value norms of general college students on each of the six AVL scales, with the greatest differences revealed in the Religious values.

Business students attached greater importance to Economic, Political $(p<.001)$ and Theoretical $(\mathrm{p} .<.01)$ values than the general college population. The general college students placed greater emphasis on Religious, Aesthetic and Social values ( $\mathrm{p}<.001)$.

Table 2 compares the value score for the male student groups.

From Tables 2, it will be noted that male business students differed significantly from the general male college students on four of the six scales. Similar to the results for the total population in Table 1, the greatest differences between the two male groups occurred in the Religious and Economic value scores. Following the patterns shown for the total population (Table 1), male business students attached significantly greater importance to Economic and Political values ( $p .<.001$ ), while the general male college students had significantly higher scores $(\mathrm{p} .<001)$ on the Religious scale. In contrast to the results 
87 Business Administration Students in Five Canadian Universities: A Study of Values

\section{TABLE 1}

Comparison of Business Students and General

College Norms on the AVL Scale

\begin{tabular}{|c|c|c|c|c|c|}
\hline \multirow[b]{2}{*}{ Values } & \multicolumn{2}{|c|}{$\begin{array}{l}\text { Business } \\
\text { Students } \\
(\mathbb{N}=513)\end{array}$} & \multicolumn{2}{|c|}{$\begin{array}{c}\text { General College } \\
\text { Students } \\
(\mathrm{N}=3,778) \\
\end{array}$} & \multirow[b]{2}{*}{$t$} \\
\hline & Mean & S.D. & Mean & S.D. & \\
\hline The oretical & 40.48 & 6.57 & 39.75 & 7.27 & $-2.16^{*}$ \\
\hline Economic & 47.54 & 7.50 & 40.33 & 7.61 & $-20.17 * * *$ \\
\hline Aesthetic & 37.20 & 7.87 & 38.88 & 8.42 & $4.27 * * *$ \\
\hline Social & 38.42 & 6.80 & 39.56 & 7.03 & $3.46 * * *$ \\
\hline Political & 45.26 & 6.56 & 40.39 & 6.44 & $-16.04 * * *$ \\
\hline Religious & 31.01 & 10.16 & 41.01 & 9.31 & $22.57 * * *$ \\
\hline
\end{tabular}

${ }^{1}$ From Allport et al., 1960, p. 12

$*_{\mathrm{p}}>.05$

$* *_{p}>.01$

$* * *_{\mathrm{p}}>.001$

\section{TABLF 2}

Comparison of Male Business Students and General Male Collegiate Norms on the AVL Scale

\begin{tabular}{|c|c|c|c|c|c|}
\hline \multirow[b]{2}{*}{ Values } & \multicolumn{2}{|c|}{$\begin{array}{c}\text { Male Business } \\
\text { Students } \\
(\mathrm{N}=349)\end{array}$} & \multicolumn{2}{|c|}{$\begin{array}{c}\text { Male College } \\
\text { Norms } \\
(\mathrm{N}=2,489)\end{array}$} & \multirow[b]{2}{*}{$\mathrm{t}$} \\
\hline & Mean & S.D. & Mean & S.D. & \\
\hline Theoretical & 41.69 & 6.26 & 43.75 & 7.34 & $-4.99 * k *$ \\
\hline Economic & 48.49 & 7.65 & 42.78 & 7.92 & $12.67 * * \pi$ \\
\hline Aes thetic & 35.20 & 7.36 & 35.09 & 8.49 & .23 \\
\hline Social & 37.69 & 6.68 & 37.09 & 7.03 & 1.50 \\
\hline Political & 46.50 & 6.20 & 42.94 & 6.64 & $9.46 * * *$ \\
\hline Religious & 30.24 & 10.11 & 38.20 & 9.32 & $-14.78 * * *$ \\
\hline
\end{tabular}

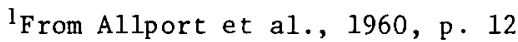

$\begin{aligned}{ }^{*} \mathrm{p} & <.05 \\ * *_{\mathrm{p}} & <.01 \\ * * * \mathrm{p} & <.001\end{aligned}$ 
$\underline{\text { TABLE } 3}$

Comparison of Female Business Students and Genera1 Female Collegiate Norms on the AVL Scale

\begin{tabular}{|c|c|c|c|c|c|}
\hline \multirow[b]{2}{*}{ Values } & \multicolumn{2}{|c|}{$\begin{array}{c}\text { Female Business } \\
\text { Students } \\
(\mathrm{N}=164) \\
\end{array}$} & \multicolumn{2}{|c|}{$\begin{array}{c}\text { Female College } \\
\text { Norms } \\
(\mathrm{N}=1,289) \\
\end{array}$} & \multirow[b]{2}{*}{$t$} \\
\hline & Mean & S.D. & Mean & S.D. & \\
\hline Theoretical & 37.91 & 6.50 & 35.75 & 7.19 & $3.66 * * *$ \\
\hline Economic & 45.52 & 6.78 & 37.87 & 7.30 & $12.74 * * * *$ \\
\hline Aesthetic & 41.26 & 7.38 & 42.67 & 8.34 & $-2.07 *$ \\
\hline Social & 39.98 & 6.81 & 42.03 & 7.02 & $-3.53 * * *$ \\
\hline Political & 42.62 & 6.55 & 37.84 & 6.23 & $8.51 * x * *$ \\
\hline Religious & 32.65 & 10.09 & 43.81 & 9.40 & $-14 \cdot 20 * * *$ \\
\hline
\end{tabular}

${ }^{\text {l} F r o m ~ A l l p o r t ~ e t ~ a l ., ~ 1960, ~ p . ~} 12$

$$
\begin{aligned}
*_{p} & <.05 \\
* *_{p} & <.01 \\
* * * *_{p} & <.001
\end{aligned}
$$

\section{TABLE 4}

\begin{tabular}{|c|c|c|c|c|c|c|c|}
\hline \multirow[b]{2}{*}{ Values } & \multicolumn{3}{|c|}{$\begin{array}{c}\text { Male Business } \\
\text { Students } \\
(\mathrm{N}=349) \\
\end{array}$} & \multicolumn{3}{|c|}{$\begin{array}{c}\text { Female Business } \\
\text { Students } \\
(\mathrm{N}=164)\end{array}$} & \multirow[b]{2}{*}{$t$} \\
\hline & Mean & (Rank) & S.D. & Mean & (Rank) & S.D. & \\
\hline Theoretical & 41.69 & (3) & 6.26 & 37.91 & (5) & 6.50 & $6.29 * * *$ \\
\hline Economic & 48.49 & (1) & 7.65 & 45.52 & (1) & 6.78 & $4.25 * * *$ \\
\hline Aesthetic & $35 \cdot 30$ & (5) & 7.36 & 41.26 & (3) & 7.38 & $-8.55 * x *$ \\
\hline Social & 37.69 & (4) & 6.68 & 39.98 & (4) & 6.81 & $-3.60 * * *$ \\
\hline Political & 46.50 & (2) & 6.20 & 42.62 & (2) & 6.55 & $6.48 * * *$ \\
\hline Re1igious & 30.24 & (6) & 10.11 & 32.55 & (6) & 10.09 & $-2.52 * *$ \\
\hline
\end{tabular}

Comparison of Male and Female Business Students on the AVL Scale

\footnotetext{
$* \mathrm{p}>.05$

$\star * \mathrm{p}>.01$

$\star * * \mathrm{p}>.001$
} 
which compared the total samples, the general male college students scored significantly higher on the Theoretical scale (p. $<.001)$ than did male business students. Although no significant differences are indicated for the Aesthetic and Social scales between the two groups, it is interesting to note that the mean scores for these values are higher for male business students. This is in contrast to the results which compared the total populations in Table 1.

The difference between female business students and the general female college norms for the value scales are presented in Table 3.

A comparison of AVL mean scores shows statistically significant differences on all six scales. The data in the table also indicate that the trend (direction of differences) established for total population was maintained between the two female groups. Except for the difference on the Aesthetic scale $(p .<.01)$, the differences on the remaining five scales were at .001 level of confidence. In line with the results in Table 1, female business students scored higher on Theoretical, Economic and Political scales while general female college students scored higher on Aesthetic, Social and Religious scales.

\section{Business Students: Value Differences by Sex}

Table 4 shows the findings related to the second question regarding the differences between the values of male and females business students in the five schools. In order to determine these differences, mean scores on the six AVL scales for 349 males were compared with the same scores for 164 females. As in previous comparisons, correlated t tests were used.

The ratios and probability values indicate that there were significant differences on all scales between the two groups. Male business students scored significantly higher $(\mathrm{p} .<.001)$ than did female business students on the Theoretical, Economic and Political scales, and significantly lower on the Aesthetic, Social (p. $<.001)$, and on the Religious ( $p .<.01)$ scales. It is interesting to note that, despite the differences on the mean scores, there was some degree of agreement between the two groups in ranking the scales. For four of the six values the rank position is identical. The disagreement occurred for Theoretical and Aesthetic values, which were given third and fifth position respectively by the male students, and the reverse by the female students.

\section{Business Students: Value Differences by School}

The third question considered in this study was: Are there differences in the values of business administration students in the different schools participating in this study? Table 5 presents mean scores and standard deviations for each student group in the five schools. Analysis of variance across the mean scores of all six scales resulted in only one significant $\mathrm{F}$-value.

The findings indicate a statistically significant $(\mathrm{p} .<.05)$ difference among the school mean scores on the Social scale. The students in D school had the highest mean score. Students in B school had the lowest mean score. Although the ranks for the AVL scales are not shown, a close examination of the mean scores reveals uniformity in the ranks for all scales by the students in all five schools. These ranks, which correspond with those for the total sample (Table 1) of business students investigated as well as with ranks for male business students, occurr in the following order: 1) Economic, 2) Political, 3) Theoretical, 4) Social, 5) Aesthetic, and 6) Religious. 


\section{TABLE 5}

AVL Mean Scores and Standard Deviations for the Student Groups in Each of the Five Schools

\begin{tabular}{llrrrrrr}
\hline & & \multicolumn{7}{c}{ Values } \\
\cline { 3 - 8 } Schools & \multicolumn{1}{c}{ T. } & Ec. & \multicolumn{1}{c}{ Ae. } & \multicolumn{1}{c}{ S. } & \multicolumn{1}{c}{ P. } & R. \\
\hline \multirow{2}{*}{ A $\quad$ N = 116) } & Me an & 40.41 & 46.32 & 37.83 & 38.58 & 45.14 & 31.72 \\
& SD & 6.15 & 7.27 & 7.59 & 6.32 & 5.96 & 10.15 \\
B (N = 115) & Mean & 40.37 & 47.90 & 36.70 & 37.04 & 46.33 & 31.57 \\
& SD & 6.43 & 7.32 & 7.33 & 6.98 & 7.19 & 11.10 \\
C (N = 98) & Mean & 39.10 & 47.46 & 36.97 & 39.07 & 45.38 & 31.71 \\
& SD & 6.17 & 7.08 & 9.03 & 6.55 & 6.13 & 9.06 \\
D (N = 95) & Me an & 41.06 & 47.05 & 37.31 & 39.84 & 44.60 & 30.19 \\
& SD & 7.07 & 8.20 & 8.31 & 7.61 & 6.27 & 10.52 \\
E (N = 89) & Mean & 41.62 & 49.28 & 37.18 & 37.78 & 44.61 & 29.48 \\
& SD & 7.00 & 7.51 & 7.12 & 6.23 & 7.16 & 9.61 \\
& & 1.97 & 2.15 & .32 & $2.69 *$ & 1.25 & 1.01 \\
F Value & & 1.97 & & & & & \\
\hline
\end{tabular}

d.f. 4 and 508

$*_{p}<.05$

\section{Business Students: Value Differences by Class (Year) Level}

Table 6 presents the findings relative to the fourth question of the study. $t$ ratios and probability values were utilized to analyze the differences in student values at successive class (year) levels.

The results reported in Table 6 indicate significant differences between first and second year students and between second and third year students. No significant differences were found between students enrolled in the last two years. When compared with second year students, first year students attach greater importance to Theoretical $(\mathrm{p} .<.01)$, Economic and Political $(\mathrm{p} .<.05)$ values while deemphasizing Religious ( $\mathrm{p} .<.01)$ and Aesthetic $(\mathrm{p} .<.05)$ values. The second column, comparing the values between second and third year students, shows that second year business students attach greater importance to Religious values $(\mathrm{p} .<.05)$ than do third year students. It was also found that the mean scores (not shown) for all six values were ranked in identical order by students in all class (year) levels. Since this study was crossectional it must be emphasized that the differences are between separate groups of students at the same point in time. These are not an indication of individual value changes over time. That could only be revealed through a longitudinal study.

\section{DISCUSSION}

In general, the findings of this study are similar to other studies of college students utilizing the AVL scales, as reviewed by Feldman and Newcomb (1969). They support 


\section{TABLE 6}

$t$ Test of Differences Between Means of Business Students on AVL Scale, by Class Level

\begin{tabular}{lcccc}
\hline & \multicolumn{4}{c}{ Class Leve1 } \\
\cline { 2 - 5 } Values & Years 1-2 & Years $2-3$ & Years $3-4$ & Years 1-4 \\
Theoretical & $2.60 * *$ & -1.49 & .57 & 1.65 \\
Economic & $2.12^{*}$ & -1.29 & -1.77 & -1.07 \\
Aesthetic & $-2.13^{*}$ & 1.47 & .66 & -.55 \\
Social & -.37 & -.09 & -.41 & -.31 \\
Political & $2.36 *$ & $-2.30 *$ & -.26 & -.90 \\
Religious & $-2.84 * *$ & $2.22 *$ & 1.53 & 1.06 \\
\hline
\end{tabular}

${ }^{*} \mathrm{p}<.05$

$\star \star p<.01$

the general conclusion that students in different major fields can be distinguished in terms of values and personality attitudes.

Compared with the value norms for the general college population, students of business administration in this study ranked Economic and Political values significantly higher. By contrast, business students scored considerably lower on Aesthetic, Social and Religious value scales.

On the Theoretical scale, however, the results of this study did not conform to the findings reported by Feldman and Newcomb $(1969$, p.158). In summarizing the studies concerned with major field differences, they concluded that business administration students (as well as those in humanities) ranked predominantly low on the theoretical scale compared to the norms for the general college population. Major curriculum changes in business administration programs during the past decade have resulted in greater emphasis upon such disciplines as quantitative methods, information systems and computer science. This may explain a shift in orientation toward Theoretical values on the part of business administration students.

There were differences on all six scales between the values of male and female business students. This finding parallels much of the previous research elsewhere. However, the relative weighting accorded to each scale and the rank order was similar for the two groups. These similarities tend to temper the interpretation of the data which, at first glance, appears to show marked differences.

The analysis of student values categorized by schools indicated little variance among business students in the five schools. It was concluded that the effect of different schools on the values of students was minimal.

Although value differences were found to exist among business students in different stages of the program, these were not of sufficient magnitude to yield any changes in the relative rankings of the values. Economic and Political values remained highest, followed by Theoretical, Social, Aesthetic and Religious values in descending order. It should be 
noted that these rankings were consistent with most of the comparisons prepared in this study.

The findings point to significant differences in the values between American general college students and the Canadian business administration students. Moreover, the mean scores and the ranks of values reported here are consistent with studies of American business administration students reported by Allport et al., (p.14). This would seem to indicate a business administration student profile different from the general college student profile. Based on the results and the interpretation usually given to AVL scales, the business student may be described as someone more oriented to practical and utilitarian matters, interested primarily in applied knowledge, and motivated to seek positions of power, influence and tangible reward. One might well suppose that these basic interests and attributes influence his career and educational choices.

\section{CONCLUSION}

It is evident that students in business schools attach high value to the Economic and Political areas of interest, both at the point of entry and throughout their undergraduate years. These two values would seem to be reinforced consistently throughout the business program.

The Theoretical value scores, which are generally associated with higher intellectual characteristics and scholarship, rank third on the AVL scale. Despite the results that business students in this study had a higher mean score on the Theoretical scale than did the general college population, the scores are still well below those of students in most other professional colleges (Allport, et al., 1960, p.14,15). This might suggest that the commonly accepted goal of business schools to develop the theoretical base of their curriculum has so far been only partially realized.

It was earlier proposed that the process of admission and selection to colleges experi: encing increased enrollment will likely call for additional information about the applicants, and for innovative methods of acquiring it. Certain other professional colleges have been forced to refine their selection process because of an unmanageable volume of applicants. Their experience indicates that when information is sought beyond academic performance and character references, it usually involves some aspects of values and personality attributes. Efforts to develop adequate methods for assessing these areas must be preceded by prior study about the values of the present college population, and its possible relationship to outcomes of achievement in school and career.

The general notion that different value systems exist among students in different curricular programs was supported by this study. These results suggest the need for further research. Longitudinal studies would be particularly useful to examine pre-college attitudes, to analyze the effects of the college program itself, and to relate the value profile of students to their performance. The present research hopefully makes a beginning contribution toward this end by suggesting some norms in the value profile of the Canadian business college student.

\section{REFERENCES}

Allport, G.W., Vernon, P. E., and Lindzey, G., Manual, Study of Values (3rd ed.). Cambridge: Houghton Mifflin, 1960 
93 Business Administration Students in Five Canadian Universities: A Study of Values

Feldman, K., and Newcomb, T. M., Impact of College on Students, San Francisco: Jossey-Bass, 1969

Garvin, B. J., "Values of Male Nursing Students", Nursing Research, 1976, 25, 352-357.

Gartner, S.R., "Nursing Majors in Twelve Western Universities: A Comparison of Registered Nurse Students and Basic Senior Students", Nursing Research, 1968, 17, 121-129.

Jacob, P. E., Changing Values in College, New York: Harper, 1957.

Morris, C., Varieties of Human Value, Chicago: University of Chicago Press, 1956.

Nie, N.H., and Others, Statistical Package for the Social Sciences, New York: McGraw Hill Co., 1970.

Spranger, E., Type of Men, Halle, Germany: Niemeyer, 1928.

Statistics Canada, Fall Enrolment in Universities, Catalogue No. 81-204. Ottawa: Queen's Printer, Annual. 